\title{
nature
}

\section{Credible politics versus incredible consensus}

Open and even scientifically contentious debates about pollcy Issues are, on balance, beneficial. In that context, recent signals from Europe are encouraging, whereas those from the US Congress are dispiriting.

S cientific research is a human pursuit in which both passionate commitment to conflicting ideas and personal antipathies can lead to friction between those pursuing the same goal. Most would agree that an objective reality will eventually be reached, and that ultimately it is this that counts. But such arguments, especially when based on genuine intellectual differences, loom large when the scientific understanding critical to political and regulatory decisions is incomplete. If the public handling of such controversies is an indicator of political maturity, one country at least is showing signs of regression.

Scientific protagonists in policy debates who have a real or perceived non-scientific agenda do not help. For that reason, moves to circumvent such problems by Jacques Santer, president of the European Commission (EC), are welcome, if belated. His wish to distance the EC's suppliers of scientific advice relating to health and consumer protection from directorates associated with supply industries may boost the public's shaky confidence in Brussels procedures (see page 285). His bid for more openness in their proceedings could also help to avoid situations in which conflicting interests lead to bad practice.

The perception of a non-scientific agenda has also undermined the ability of Nirex, the UK agency responsible for the long-term disposal of nuclear waste, to make its case for the development of an underground repository. Last week's report by the Radioactive Waste Management Advisory Committee on Nirex's peer-review procedures highlighted the boost of confidence in that organization's scientific thinking on issues such as rock hydrology that followed an independent review by a panel appointed by the Royal Society. It is, in fact, not easy to find scientists with relevant expertise who have not at some point been associated either with Nirex or its environmentalist opponents. But a learned society is in as good a position as anyone to stand back and deliver an impartial assess- ment incorporating what they have to say.

Involving academies and learned societies in order to increase public confidence has its own difficulties, however. Their members will not (and should not) take kindly to the adoption of any recommendation that goes beyond what is scientifically uncontentious. And a new potential obstacle has emerged in the United States, following a legal ruling that, where its advice has been sought by government agencies, the National Academy of Sciences must conduct its deliberations in public. The academy is likely to appeal, stating that this would tie its hands by forcing scientists to make a public defence of views which they may prefer to express privately.

Even with the most perfectly balanced and disinterested statement of current knowledge and uncertainties, there is another step to be taken before reaching any political or regulatory decision. Where the costs are obvious and the evidence of benefits is ambiguous, contention frequently arises. The stage is set for just such a controversy in a forthcoming debate in the US Congress about proposed regulations to decrease ground-level concentrations of ozone and particles in the atmosphere. A surprising weakness in the political process is emerging. Members of Congress, as their staff members admit (see page 284), often fail to distinguish between scientific uncertainties and political controversies. For them, open debate of scientific differences is seen as damaging to a belief that science can contribute usefully. Admittedly such debates can be hijacked by pressure groups. But they also have the potential virtues of increasing public understanding of and confidence in the eventual decisions.

Just as overly secretive and interest-bound bodies in Europe are becoming more open and independent, the country that many Europeans see as a model of open debate seems to be becoming increasingly reluctant to deal with intellectual contention in a mature manner.

\section{Xenotransplantation: the heart of the matter}

\section{The BSE crisis has concentrated the British government's thinking about xenotransplantation.}

W

hat a difference a year makes. It is just over twelve months since the British government rejected a proposal from a parliamentary committee to set up a statutory body to regulate genetic research and its applications. Now, after the crisis over bovine spongiform encephalopathy (BSE), it is singing a different tune, promising tough regulations to protect individuals from the potential dangers of transplanting organs from animals to humans. Last week's announcement of a Xenotransplantation Interim Regulatory Authority reflects the thoroughness with which an advisory group set up to examine the ethics involved has done its task (see page 285). For it needs to be acknowledged more widely that there are public, and not just personal, health issues at stake.

Much current concern focuses on the possible transmission of dormant retroviruses from animals to man, perhaps to become expressed only after several years. If this were to happen, there is a theoretical chance that the virus could spread to other individuals from those receiving transplants. The AIDS epidemic, which is generally believed to have originated in a monkey virus, is a gruesome reminder of the potential consequences.

Caution is therefore to be applauded. A key issue to be faced by the new regulatory body is whether the apparent lack of expression of retroviruses in monkeys used in experimental transplantation of pig organs is sufficient to allow clinical trials on humans, or whether these should be delayed until we have sufficient detailed knowledge of the pig genome to 'breed out' the offending DNA. While commercial (and even medical) pressure may favour the first, there are good reasons for adopting the second. The same philosophy could beneficially be followed by other agencies, such as the US Food and Drug Administration, which have been considering more moderate measures. The one lesson to be learnt from the recent BSE crisis is "never say 'never". 